\title{
Pengaruh Pengelolaan Kelas dan Minat Belajar terhadap Hasil Belajar Siswa pada Mata Pelajaran Ekonomi Kelas X di SMA Negeri 8 Kota Jambi
}

\author{
Redi Indra Yudha \\ Dosen Program Studi Pendidikan Ekonomi, FKIP UNBARI \\ Correspondence email: ilcapitanojuventus@ rocketmail.com
}

\begin{abstract}
Abstrak: Penelitian ini bertujuan untuk mengetahui gambaran responden dan pengaruh mengenai pengelolaan kelas dan minat belajar terhadap hasil belajar siswa pada mata pelajaran ekonomi kelas X di SMA Negeri 8 Kota Jambi. Berdasarkan analisis data pada hasil penelitian bahwa terdapat pengaruh yang signifikan antara pengelolaan kelas dan minat belajar terhadap hasil belajar siswa pada mata pelajaran ekonomi kelas X di SMA Negeri 8 Kota Jambi. Dengan hasil model summary $\mathrm{R}=0,067$ dan $\mathrm{R}$ Square $=0,004$. Pada ANOVA, nilai $\mathrm{F}=69,368$ dengan $\alpha(\mathrm{sig})=0,003$. Oleh karena $\alpha(\mathrm{Sig})<0,05$, maka regresi dapat digunakan untuk memprediksi pengelolaan kelas dan minat belajar pada taraf kepercayaan 95\%. Berdasarkan nilai B constant untuk X, dapat dibuat suatu persamaan regresi yaitu $\mathrm{Y}=\mathrm{a}+\mathrm{X} 1+\mathrm{X} 2=64,046+0,201+0,291$. Dan, untuk thitung X1 = 2,010, dan t hitung X2 $=2,856$ maka $\mathrm{t}$ hitung $>\mathrm{t}$ tabel. Hal ini berarti, bahwa $\mathrm{t}$ hitung $>\mathrm{t}$ tabel. Artinya, hasil uji $\mathrm{t}$ ini menunjukkan bahwa pengelolaan kelas (X1) dan minat belajar (X2) mempunyai pengaruh yang positif dan signifikan terhadap hasil belajar (Y) siswa kelas X mata pelajaran ekonomi di SMA Negeri 8 Kota Jambi.
\end{abstract}

Kata Kunci: Pengelolaan Kelas, Minat Belajar, Hasil Belajar.

Abstract: This study aims to determine the description of respondents and the influence of classroom management and interest in learning on student learning outcomes on the subjects of economy class X in SMA Negeri 8 Kota Jambi. Based on data analysis on the results of research that there is a significant influence between classroom management and interest in learning of student learning outcomes on the subjects of economy class X in SMA Negeri 8 Kota Jambi. With result of model summary $R=0,067$ and $R$ Square $=0,004$. In ANOVA, the value of $F=69,368$ with $\alpha($ sig $)=0.003$. Because $\alpha($ Sig) $<0.05$, then regression can be used to predict classroom management and interest in learning at $95 \%$ confidence level. Based on the value of B constant for X, we can make a regression equation that is $Y=a+X 1+X 2=64,046+0,201+0,291$. And, for t arithmetic X1 $=2.010$, and t arithmetic $X 2=2.856$ then $t$ arithmetic $>t$ table. This means that $t$ count $>t$ table. This means that the results of this $t$ test indicate that the classroom management (X1) and interest in learning (X2) have a positive and significant impact on the learning outcomes $(Y)$ of the students of class $X$ economic subjects in SMA Negeri 8 Kota Jambi.

Keyword: Classroom Management, Interest in Learning, Learning Outcomes.

\section{PENDAHULUAN}

Sekolah adalah suatu lembaga yang memang dirancang khusus untuk pengajaran para murid (siswa) di bawah pengawasan para guru. Kebanyakan dalam sebuah negara mempunyai model sistem pendidikan formal yang mana hal ini sifatnya wajib. Selain itu sistem ini juga yang membuat para siswa bisa mengalami kemajuan dengan melalui serangkaian sekolah tersebut. Adapun nama dari masing-masing sekolah juga bervariasi berdasarkan negara itu sendiri, namun kebanyakan sekolah dasar untuk anak-anak muda sementara sekolah menengah untuk para remaja yang sudah menyelesaikan pendidikan dasar mereka. Sekolah yang pada dasarnya sebagai sarana untuk melaksanakan pendidikan memang diharapkan bisa menjadikan masyarakat yang lebih maju, oleh sebab itu sekolah sebagai pusat dari pendidikan harus bisa melaksanakan fungsinya dengan optimal dan perannya dalam menyiapkan para generasi muda sebelum mereka terjun di dalam proses pembangunan masyarakat.

Proses pembelajaran merupakan salah satu sistem untuk meningkatkan kualitas pendidikan. Oleh sebab itu sekolah menyediakan berbagai fasilitas belajar untuk menunjang para siswa belajar dengan baik dan nyaman, sehingga dapat memacu siswa dalam proses belajar. Fasilitas belajar berperan dalam mempermudah dan memperlancar kegiatan belajar siswa. Macam-macam fasilitas belajar seperti tempat belajar, peralatan tulis, media belajar, dan fasiltas lainnya. Dimana, fasilitas belajar mempermudah siswa dalam memecahkann masalah-masalah yang timbul sewaktu mempelajari dan memahami pelajaran atau tugas yang diberikan oleh guru. Misalnya, seorang siswa mengerjakan tugas yang diberikan oleh guru, sedangkan siswa tersebut kurang atau tidak memiliki fasilitas belajar yang menunjang untuk mengerjakan tugas tersebut yang kemungkinan dapat menghambat terselesainya tugas. Sebaliknya, jika siswa mempunyai fasilitas belajar yang lengkap, maka tugas dari guru dapat dikerjakan dengan baik. Jadi, apabila siswa mendapat fasilitas belajar yang baik dan didukung oleh kemampuan siswa dalam memanfaatkannya secara optimal diharapkan dapat meningkatkan hasil belajar siswa.

Untuk menyatakan bahwa suatu proses belajar dapat dikatakan berhasil, setiap guru memiliki pandangan masing-masing sejalan dengan filsafatnya. Namun, untuk menyamakan persepsi sebaiknya kita berpedoman pada 
kurikulum yang berlaku saat ini yang telah disempurnakan, antara lain bahwa suatu proses belajar mengajar tentang suatu bahan pembelajaran dinyatakan berhasil apabila tujuan pembelajaran khususnya dapat dicapai. Dengan demikian, dapat dikatakan bahwa hasil belajar adalah prestasi belajar yang dicapai siswa dalam proses kegiatan belajar mengajar dengan membawa suatu perubahan dan pembentukan tingkah laku seseorang. Adapun agar menciptakan suasana belajar yang efektif sehingga dapat meningkatkan hasil belajar siswa perlu adanya pengelolaan kelas yang baik.

Adapun faktor lainnya yang dapat mempengaruhi hasil belajar yaitu minat belajar siswa. Minat merupakan faktor yang sangat penting dalam menentukan hasil belajar siswa. Dengan adanya minat maka rangsangan yang timbul akan meningkatkan semangat dalam diri siswa, maka ia akan mendapatkan kepuasan batin dengan hasil belajar yang baik yang telah dicapai. Sebaliknya, suatu kegiatan yang tidak dilakukan sesuai dengan minat akan menghasilkan hasil belajar yang kurang memuaskan. Tanpa minat yang kuat, sangat sulit bagi seorang siswa untuk mencapai prestasi yang maksimal.

Dengan demikian, suatu kondisi belajar yang optimal dapat tercapai jika guru mampu mengatur anak didiknya dan sarana pengajaran serta mengendalikannya dalam suasana yang menyenangkan untuk mencapai tujuan pengejaran. Hubungan interpersonal yang baik antara guru dan anak didik, merupakan syarat keberhasilan pengelolaan kelas. Selain itu adanya fasilitas yang memadai dapat meningkatkan minat belajar pada siswa. Pengelolan kelas dan minat yang efektif merupakan syarat mutlak bagi terjadinya proses belajar mengajar yang efektif.

Djamarah (2009:174) menjelaskan bahwa pengelolaan kelas adalah salah satu tugas guru yang tidak pernah ditinggalkan. Guru selalu mengelola kelas ketika dia melaksanakan tugasnya. Pengelolaan kelas dimaksudkan untuk menciptakan lingkungan belajar yang kondusif bagi anak didik sehingga tercapai tujuan pengajaran secara efektif dan efesien. Ketika kelas terganggu, guru berusaha mengembalikannya agar tidak menjadi penghalang bagi proses belajar mengajar. Sementara, Usman (2003:5) menyatakan bahwa pengelolaan kelas yang efektif merupakan persyaratan mutlak bagi terjadinya proses belajar mengajar yang efektif.

Djamarah (2009:179-183) menjelaskan pengelolaan kelas bukanlah masalah yang berdiri sendiri, tetapi terkait dengan berbagai faktor. Permasalahan anak didik adalah faktor utama yang terkait langsung dalam hal ini. Karena pengelolaan kelas yang dilakukan guru tidak lain adalah untuk meningkatkan kegairahan belajar anak didik baik secara berkelompok maupun secara individual. Berbagai pendekatan tersebut adalah seperti dalam uraian berikut :

1. Pendekatan Kekuasaan.

Pengelolaan kelas diartikan sebagai suatu proses untuk mengontrol tingkah laku anak didik. Peranan guru disini adalah menciptakan dan mempertahankan situasi disiplin dalam kelas. Kedisiplinan adalah kekuatan yang menuntut kepada anak didik untuk menaatinya.

2. Pendekatan Ancaman.

Pengelolaan kelas adalah sebagai proses untuk mengontrol tingkah laku anak didik. Tetapi dalam mengontrol tingkah laku anak didik dilakukan dengan cara memberikan ancaman, misalnya melarang, ejekan, sindiran, dan memaksa.

3. Pendekatan Kebebasan.

Pengelolaan diartikan secara suatu proses untuk membantu anak didik agar merasa bebas untuk mengerjakan sesuatu kapan saja dan dimana saja. Peranan guru adalah mengusahakan semaksimal mungkin kebebasan anak didik.

4. Pendekatan Resep.

Pendekatan resep ini dilakukan dengan memberi suatu daftar yang dapat menggambarkan apa yang harus dan apa yang tidak boleh dikerjakan oleh guru dalam mereaksi semua masalah atau situasi yang terjadi di kelas. Dalam daftar ini digambarkan tahap demi tahap apa yang harus dikerjakan oleh guru. Peranan guru hanyalah mengikuti petunjuk seperti yang tertulis dalam resep.

5. Pendekatan Pengajaran.

Pendekatan ini didasarkan atas suatu anggapan bahwa dalam suatu perencanaan dan pelaksanaan akan mencegah munculnya masalah tingkah laku anak didik, dan memecahkan masalah itu bila tidak bisa dicegah. Pendekatan ini menganjurkan tingkah laku guru dalam mengajar untuk mencegah dan menghentikan tingkah laku anak didik yang kurang baik. Peran guru adalah merencanakan dan mengimplementasikan pelajaran yang baik.

6. Pendekatan Perubahan Tingkah Laku.

Sesuai dengan namanya, pengelolaan kelas diartikan sebagai suatu proses untuk mengubah tingkah laku anak didik. Peranan guru adalah mengembangkan tingkah laku anak didik yang baik, dan mencegah tingkah laku anak didik yang baik

7. Pendekatan Suasana Emosional dan Hubungan Sosial. 
Pendekatan pengelolaan kelas berdasarkan suasana perasaan dan suasana sosial di dalam kelas sebagai kelompok individu cenderung pada pandangan psikologi klinis dan konseling. Menurut pendekatan ini pengelolaan kelas merupakan suatu proses menciptakan iklim atau suasana emosional dan hubungan sosial yang positif dalam kelas.

8. Pendekatan Proses Kelompok.

Pengelolaan kelas diartikan sebagai suatu proses untuk menciptakan kelas sebagai suatu sistem sosial, dimana proses kelompok merupakan yang paling utama. Peranan guru adalah mengusahakan agar perkembangan dan pelaksanaan proses kelompok itu yang efektif.

9. Pendekatan Elektis atau Pliralistik.

Pendekatan elektis ini menekankan pada potensialitas, kreatifitas, dan inisiatif wali atau guru kelas dalam memilih berbagai pendekatan tersebut berdasarkan situasi yang diharapkannya. Penggunaan pendekatan ini dalam situasi mungkin dipergunakan salah satu dan dalam situasi lain mungkin harus dapat dikombinasikan dan atau ketiga pendekatan tersebut.

Suatu minat dapat diekspresikan melalui suatu pernyataan yang menunjukkan bahwa siswa lebih menyukai suatu hal daripada lainnya, yang dapat pula dimanifestasikan melalui partsipasi dalam suatu aktivitas. Siswa yang memiliki minat terhadap subjek tertentu cenderung untuk memberikan perhatian yang lebih besar terhadap subjek tersebut. Ahmadi, dkk (2013:83) menjelaskan tidak adanya minat seseorang terhadap suatu pelajaran akan menimbulkan kesulitan belajar. Belajar dengan minat akan mendorong siswa belajar dengan baik dari pada belajar tanpa minat. Namun demikian, minat tanpa adanya usaha yang baik maka belajar juga akan sulit untuk berhasil.

Sementara, Putra (2011:21) menjelaskan minat yang kuat akan menimbulkan usaha yang gigih serius dan tidak mudah putus asa dalam menghadapi tantangan, jika seseorang siswa ingin memiliki rasa ingin belajar, maka siswa akan cepat mengerti dan mengingatnya. Fungsi minat bagi kehidupan anak, salah satunya yaitu minat sebagai pendorong tenaga yang kuat serta prestasi selalu dipengaruhi oleh jenis dan intensitas minatnya. Adapun indikator minat belajar menurut Dimyati, dkk (2005:60), dapat diuraikan sebagai berikut :

1. Perasaan Senang.

Adalah perasaan momentan dan itensional. Momentan adalah perasaan yang muncul pada saat-saat tertentu, intensional adalah reaksi dari perasaan yang diberikan terhadap suatu hal-hal tertentu. Perasaan disini dibagi menjadi dua, yaitu perasaan senang dan perasaan tidak senang, sehingga dalam perasaan itu akan timbul sebuah sikap.

2. Ketertarikan Siswa.

Berhubungan dengan daya gerak yang mendorong untuk cenderung merasa tertarik pada orang, benda, kegiatan atau bisa berupa pengalaman efektif yang dirangsang oleh kegiatan itu sendiri.

3. Perhatian.

Perhatian sangatlah penting dalam mengikuti kegiatan dengan baik, dan hal ini akan berpengaruh terhadap minat siswa dalam belajar. Perhatian adalah pemusatan tenaga psikis yang tertuju pada suatu objek yang datang dari luar dan dalam individu, aktivitas yang disertai dengan perhatian intensif akan lebih sukses dan prestasinya akan lebih tinggi. Oleh karena itu, seseorang yang mempunyai perhatian terhadap suatu pelajaran, dia pasti akan berusaha keras untuk memperoleh nilai yang bagus yaitu akan memberikan perhatian lebih, memiliki konsentrasi dalam belajar dan mengikut penjelasan guru serta mengerjakan tugas-tugas yang diberikan.

Pelajaran akan berjalan dengan lancar apabila ada minat. Anak-anak malas, tidak belajar, gagal karena tidak ada minat. Dalam kegiatan belajar, minat mempunyai peranan yang sangat penting. Bila seseorang siswa tidak memiliki minat dan perhatian besar terhadap suatu objek yang dipelajari maka sulit diharapkan siswa tersebut akan tekun dan memperoleh hasil yang baik dari belajarnya. Sebaliknya, apabila siswa tersebut belajar dengan minat dan perhatian yang besar terhadap yang mempengaruhi suatu obejek yang dipelajari, maka hasil yang diperoleh lebih baik.

Purwanto (2014:46) menjelaskan bahwa hasil belajar merupakan perubahan perilaku yang terjadi setelah mengikuti proses belajar mengajar sesuai dengan tujuan pendidikan. Manusia mempunyai potensi perilaku kejiwaan yang dapat dididik dan diubah perilakunya yang meliputi domain kognitif, efektif dan psikmotorik. Sementara, Sudjana (2009:22) mengemukakan bahwa hasil belajar adalah kemampuan yang dimiliki siswa setelah ia menerima pengalaman belajarnya. Dimana kemampuan tersebut dapat dibedakan menjadi tiga macam hasil yaitu (a) keterampilan dan kebiasaan, (b) pengetahuan dan pengertian, (c) sikap dan cita-cita. Sedangkan, Thidhomanto (2010:45) menjelaskan bahwa hasil belajar adalah perubahan yang mengakibatkan manusia berubah dalam sikap dan tingkah lakunya. Aspek perubahan itu mengacu kepada taksonomi tujuan pengajaran yang dikembangkan oleh Bloom, Sompson dan Harrow mencakup aspek kognitif, afektif dan psikomotorik.

Dengan demikian, agar pengelolaan kelas dapat berjalan dengan baik, dan minat belajar siswa meningkat sesuai dengan tujuan maka dibutuhkan suatu kemampuan guru sebagai prasyarat yang diantaranya adalah kemampuan untuk menata lingkungan belajar yang kondusif sehingga minat belajar siswa lebih baik. Dengan adanya pengelolaan kelas dalam hal ini penataan lingkungan belajar diharapkan dapat memberikan stimulasi terhadap peserta didik, sehingga 
Redi Indra Yudha, Pengaruh Pengelolaan Kelas dan Minat Belajar terhadap Hasil Belajar Siswa pada Mata Pelajaran Ekonomi Kelas X di SMA Negeri 8 Kota Jambi

peserta didik terpengaruh atau terkondisikan oleh lingkungan agar minat belajar siswa meningkat, sehingga hasil belajar yang tercapai oleh siswa menjadi lebih baik.

\section{METODE}

Dalam melakukan penelitian dan untuk melihat hasil penelitian dari perhitungan-perhitungan instrumen yang digunakan, maka digunakan metode analisis data. Adapun metode analisis data yang digunakan dalam penelitian ini adalah metode analisis regresi linear berganda. Dimana, dalam menganalisis pengukuran yang menguji pengaruh Pengelolaan Kelas (X1) dan Minat Belajar (X2) terhadap Hasil Belajar (Y) siswa kelas X pada mata pelajaran ekonomi di SMA Negeri 8 Kota Jambi. Dengan menggunakan estimasi : $Y=a+b_{1} X_{1}+b_{2} X_{2}+e$. Dalam penelitian, tingkat pengukuran dan pengaruh antar variabel dapat diukur dengan menggunakan uji antara satu variabel instrumen dengan variabel instrumen lainnya. Dimana, hal ini dilakukan untuk melihat apakah ada pengaruh atau tidaknya variabel-variabel yang digunakan tersebut.

Untuk mengetahui gambaran-gambaran yang ada dalam penyebaran kuesioner yang dilakukan maka digunakan analisis deskriptif. Deskriptif yang oleh Syekh (2011:15) dijelaskan sebagai suatu metode dalam meneliti suatu kelompok manusia, suatu objek, suatu kondisi suatu sistem pemikiran dengan suatu tujuan untuk membuat deskripsi, gambaran yang sistematis sesuai fakta yang sedang diselidiki. Selanjutnya, dikatakan bahwa jika kita ingin meneliti satu dua aspek yang sudah dipetakan maka kita harus masuk kedalam penelitian yang lebih mendalam. Dengan menggunakan variabel Pengelolaan Kelas (X1), Minat Belajar (X2) dan Hasil Belajar (Y), maka dalam analisa data penelitian akan menggunakan uji validitas dan uji reliabilitas dalam uji persyaratan data yang dilakukan. Sementara, untuk analisisnya sendiri menggunakan uji analisis regresi linier berganda.

\section{HASIL DAN PEMBAHASAN}

Tanggapan responden atau para siswa pada pengelolaan kelas dan minat belajar terhadap hasil belajar siswa kelas X pada mata pelajaran ekonomi di SMA Negeri 8 Kota Jambi dapat dilihat dari pilihan kriteria jawaban setiap item pertanyaan yang telah dikembangkan berdasarkan indikator dari variabel lingkungan sekolah dan disiplin belajar terhadap hasil belajar siswa, sebagai berikut :

Tabel 1 Distribusi Frekuensi Skor Variabel Pengelolaan Kelas (X1)

\begin{tabular}{clcccc}
\hline No & \multicolumn{1}{c}{ Indikator } & Skor Total & Rerata & TCR & Keterangan \\
\hline 1. & Kesukacitaan & 619,50 & 3,16 & 78,94 & Cukup Baik \\
2. & Ketertarikan & 625,50 & 3,20 & 79,95 & Cukup Baik \\
3. & Perhatian & 620,67 & 3,17 & 79,14 & Cukup Baik \\
4. & Keterlibatan & 594 & 3,65 & 68,60 & Cukup Baik \\
& Jumlah & $\mathbf{6 0 8 , 5 5}$ & $\mathbf{3 , 9 5}$ & $\mathbf{7 6 , 6 3}$ & Cukup Baik \\
\hline
\end{tabular}

Sumber : Data Diolah, Tahun 2016.

Tabel 2 Distribusi Frekuensi Skor Variabel Minat Belajar (X2)

\begin{tabular}{clcccc}
\hline No & \multicolumn{1}{c}{ Indikator } & Skor Total & Rerata & TCR & Keterangan \\
\hline 1. & Perasaan Senang & 634,50 & 3,06 & 61,28 & Cukup Baik \\
2, & Ketertarikan Siswa & 607,50 & 3,08 & 61,54 & Cukup Baik \\
3. & Perhatian & 634,50 & 3,26 & 65,17 & Cukup Baik \\
& Jumlah & $\mathbf{6 4 2 , 6 7}$ & $\mathbf{3 , 1 5}$ & $\mathbf{6 2 , 5 3}$ & Cukup Baik \\
\hline
\end{tabular}

Sumber: Data Diolah, 2016.

Pengujian normalitas data dalam suatu penelitian secara ilmiah dapat dilakukan dengan menggunakan teknik Uji Kolmogorov Smirnov-Test (Uji K-S) sebagai pengukur terhadap instrumen penelitian yang dijadikan tolok ukur dalam suatu penelitian.

Tabel 3 Hasil Uji Normalitas Data One-Sample Kolmogorov-Smirnov Test

\begin{tabular}{|ll|r|r|r|}
\hline & & Pengelolaan & Minat & HasilBelajar \\
\hline $\mathrm{N}$ & & 167 & 167 & 167 \\
Normal Parameters $^{\mathrm{a}}$ & Mean & 39.8862 & 57.5329 & 69.3413 \\
& Std. Deviation & 5.01134 & 6.68011 & .080 \\
Most Extreme Differences & Absolute & .096 & .09374 \\
& Positive & .077 & .042 & .136 \\
& & .136
\end{tabular}


Redi Indra Yudha, Pengaruh Pengelolaan Kelas dan Minat Belajar terhadap Hasil Belajar Siswa pada Mata Pelajaran Ekonomi Kelas X di SMA Negeri 8 Kota Jambi

\begin{tabular}{|lr|r|r|} 
& Negative & -.096 & -.080 \\
Kolmogorov-Smirnov Z & & 1.239 & 1.033 \\
Asymp. Sig. (2-tailed) & & .139 & .107 \\
\hline
\end{tabular}

a. Test distribution is Normal.

Hubungan (korelasi) antara variabel Pengelolaan Kelas (X1) dan Minat Belajar (X2) terhadap Hasil Belajar (Y) siswa kelas X mata pelajaran ekonomi di SMA Negeri 8 Kota Jambi. Untuk menguji Hipotesis akan diuji dengan menggunakan alat Statistik Koefisien Korelasi. Dari struktur analisis linear akan dilakukan analisis untuk mengetahui tingkat signifikansi dan nilai koefisien dari masing-masing variabel independen terhadap variabel dependen untuk substruktur dari analisis regresi linear sederhana.

Tabel 5. Hasil Analisis Estimasi Regresi Variabel Pengelolaan Kelas (X1) dan Minat Belajar (X2) Terhadap Hasil Belajar (Y) Siswa Kelas X Mata Pelajaran Ekonomi di SMA Negeri 8 Kota Jambi Coefficients $^{\mathrm{a}}$

\begin{tabular}{|c|c|c|c|c|c|}
\hline \multirow[b]{2}{*}{ Model } & \multicolumn{2}{|c|}{ Unstandardized Coefficients } & Standardized Coefficients & $\mathrm{T}$ & Sig. \\
\hline & B & Std. Error & Beta & & \\
\hline (Constant) & 64.046 & 8.674 & & 7.384 & .000 \\
\hline Pengelolaan & .201 & .142 & .001 & 2.010 & .002 \\
\hline Minat & .291 & 106 & .067 & 2.856 & .003 \\
\hline
\end{tabular}

a. Dependent Variable: Hasil Belajar

Berdasarkan tabel di atas, diperoleh suatu analisis model estimasi regresi linear berganda adalah $\mathrm{Y}=64,046+$ $0,201 X_{1}+0,291 X_{2}$. Hasil dari analisis model estimasi regresi linear berganda diperoleh nilai konstanta sebesar 64,046. Ini menunjukkan bahwa tanpa adanya pengelolaan kelas dan minat belajar terhadap hasil belajar pada mata pelajaran ekonomi kelas X SMA Negeri 8 Kota Jambi telah mencapai 64,046\%. Artinya, bagi siswa kelas X di SMA Negeri 8 Kota Jambi, faktor-faktor tersebut menjadi penting atau tidak penting untuk menentukan kelancaran aktivitas dan tugas-tugas pada pelajaran tersebut.

Gambaran Pengelolaan Kelas (X1) dan Minat Belajar (X2) Terhadap Hasil Belajar (Y) Siswa Kelas X Pada Mata Pelajaran Ekonomi di SMA Negeri 8 Kota Jambi

Berdasarkan perhitungan diketahui bahwa pengelolaan kelas di SMA Negeri 8 Kota Jambi yang terdiri dari kesukacitaan, ketertarikan, perhatian, dan keterlibatan, serta hubungan antar variabel termasuk kategori cukup baik, seperti dikemukakan oleh 149 orang responden atau sebesar 76,63\%. Hal ini berarti pengelolaan kelas yang ada di SMA Negeri 8 Kota Jambi dapat dinyatakan cukup baik. Sementara, pada variabel minat belajar siswa di SMA Negeri 8 Kota Jambi berdasarkan perhitungan yang telah dilaksanakan, dimana variabel ini sendiri terdiri dari perasaan senang, ketertarikan siswa dan perhatian, serta hubungan antar variabel termasuk kategori cukup baik, seperti dikemukakan oleh 149 orang responden atau sebesar 62,53\%. Hal ini berarti minat belajar siswa yang ada di SMA Negeri 8 Kota Jambi dapat dinyatakan cukup baik.

Pengaruh Pengelolaan Kelas (X1) Terhadap Hasil Belajar (Y) Siswa Kelas X Pada Mata Pelajaran Ekonomi di SMA Negeri 8 Kota Jambi

Berdasarkan hasil perhitungan dapat diinterprestasikan bahwa data pengelolaan kelas terhadap hasil belajar siswa kelas X pada mata pelajaran ekonomi di SMA Negeri 8 Kota Jambi dinyatakan varian homogen karena $\mathrm{F}$ hitung $<\mathrm{F}$ tabel. Dengan hasil model summary $\mathrm{R}=0,004$ dan $\mathrm{R}$ Square $=0,000$. Pada ANOVA, nilai $\mathrm{F}=9,563$ dengan $\alpha$ $(\mathrm{sig})=0,000$. Oleh karena $\alpha(\mathrm{Sig})<0,05$, maka regresi dapat digunakan untuk memprediksi pengelolaan kelas pada taraf kepercayaan 95\%. Pada coefficient nilai B constant $=69,652$, menyatakan bahwa jika variabel pengelolaan kelas diabaikan, maka hasil belajar $=69,652$. Sedangkan, nilai variabel untuk pengelolaan kelas (X1) adalah 0,141, menyatakan bahwa jika tingkat pengelolaan kelas seperti dilibatkan, maka hasil belajar meningkat sekitar 0,141.

Dengan demikian, keterampilan mengelola kelas adalah suatu usaha yang dilakukan oleh penanggung jawab kegiatan belajar mengajar atau yang membantu dengan maksud agar tercapai kondisi yang optimal sehingga dapat terlaksana kegiatan belajar seperti yang diharapkan (Djamarah, 2009:67-68). Dengan kata lain, untuk menciptakan dan mempertahankan kondisi yang optimal bagi terjadinya proses belajar mengajar, yang termasuk di dalamnya adalah penghentian tingkah laku siswa yang menyelewengkan dari perhatian kelas, pemberian ganjaran bagi ketetapan waktu penyelesaian tugas oleh siswa, atau penetapan norma kelompok yang produktif (Usman, 2003:97). 


\section{Pengaruh Minat Belajar (X2) Terhadap Hasil Belajar (Y) Siswa Kelas X Pada Mata Pelajaran Ekonomi di SMA Negeri 8 Kota Jambi}

Berdasarkan hasil perhitungan dapat diinterprestasikan bahwa data minat belajar terhadap hasil belajar siswa kelas X pada mata pelajaran ekonomi di SMA Negeri 8 Kota Jambi dinyatakan varian homogen karena $\mathrm{F}$ hitung $<\mathrm{F}$ tabel. Dengan hasil model summary $\mathrm{R}=0,067$ dan R Square $=0,004$. Pada ANOVA, nilai F $=9,740$ dengan $\alpha(\operatorname{sig})=$ 0,031. Oleh karena $\alpha$ (Sig) $<0,05$, maka regresi dapat digunakan untuk memprediksi minat belajar pada taraf kepercayaan 95\%. Pada coefficient nilai B constant $=64,109$, menyatakan bahwa jika variabel minat belajar diabaikan, maka hasil belajar $=64,109$. Sedangkan, nilai variabel untuk minat belajar (X2) adalah 0,106, menyatakan bahwa jika tingkat minat belajar seperti dilibatkan, maka hasil belajar meningkat sekitar 0,106.

Menurut hasil penelitian Supriyatin (2010:79), dijelaskan bahwa minat siswa dalam mengikuti kegiatan belajar ditunjukkan dengan keseriusan siswa dalam mendengarkan penjelasan dari guru, serta keaktifan siswa dalam bertanya maupun menjawab pertanyaan dari guru. Ketertarikan siswa dalam mengikuti pelajaran ditunjukkan dengan memahami konsep materi yang telah diberikan oleh guru, serta mempelajari materi dengan belajar yang tekun agar memperoleh nilai yang optimal. Disamping itu, minat belajar siswa yang tinggi ditunjukkan dengan kemampuan siswa dalam mengerjakan tugas dan latihan soal tanpa diperintah oleh guru.

\section{Pengaruh Pengelolaan Kelas (X1) dan Minat Belajar (X2) Terhadap Hasil Belajar (Y) Siswa Kelas X Pada Mata Pelajaran Ekonomi di SMA Negeri 8 Kota Jambi}

Berdasarkan hasil perhitungan dapat diinterprestasikan bahwa data pengelolaan kelas dan minat belajar terhadap hasil belajar siswa kelas X pada mata pelajaran ekonomi di SMA Negeri 8 Kota Jambi dinyatakan varian homogen karena F hitung $<\mathrm{F}$ tabel. Dengan hasil model summary $\mathrm{R}=0,067$ dan $\mathrm{R}$ Square $=0,004$. Pada ANOVA, nilai $\mathrm{F}=$ 69,368 dengan $\alpha(\mathrm{sig})=0,003$. Oleh karena $\alpha(\mathrm{Sig})<0,05$, maka regresi dapat digunakan untuk memprediksi pengelolaan kelas pada taraf kepercayaan 95\%. Pada coefficient nilai B constant $=64,046$, menyatakan bahwa jika variabel X1 diabaikan, maka hasil belajar $=64,046$. Sedangkan, nilai variabel untuk pengelolaan kelas (X1) adalah 0,201, menyatakan bahwa jika tingkat pengelolaan kelas seperti dilibatkan, maka hasil belajar meningkat sekitar 0,201. Sedangkan, untuk nilai minat belajar (X2) adalah sebesar 0,291, menyatakan bahwa jika tingkat minat belajar dilibatkan maka hasil belajar meningkat 0,291.

Berdasarkan nilai B constant dan X, dapat dibuat suatu persamaan regresi yaitu $\mathrm{Y}=\mathrm{a}+\mathrm{X} 1+\mathrm{X} 2=64,046+$ $0,201+0,291$. Dan, untuk t hitung $\mathrm{X} 1=2,010$, dan $\mathrm{t}$ hitung $\mathrm{X} 2=2,856$ maka $t$ hitung $>\mathrm{t}$ tabel. Hal ini berarti, bahwa $\mathrm{t}$ hitung $>\mathrm{t}$ tabel. Artinya, hasil uji t ini menunjukkan bahwa pengelolaan kelas (X1) dan minat belajar (X2) mempunyai pengaruh yang positif dan signifikan terhadap hasil belajar (Y) siswa kelas X mata pelajaran ekonomi di SMA Negeri 8 Kota Jambi.

Dengan demikian, kemampuan guru yang baik dalam mengelola dan mengembangkan kondisi kelas yang kondusif untuk kegiatan belajar mengajar akan memberikan kesempatan siswa dapat belajar secara baik, sehingga materi pembelajaran yang disampaikan guru dapat diserap secara maksimal dan pada akhirnya akan berdampak pada pencapaian prestasi belajar yang optimal.

Menurut Djamarah (2009:194), pengelolaan kelas merupakan masalah tingkah laku yang kompleks, dan guru menggunakannya untuk menciptakan dan mempertahankan kondisi kelas sedemikian rupa, sehingga anak didik dapat mencapai tujuan pengajaran secara efisien dan memungkinkan mereka dapat belajar. Sehingga, dengan adanya pengelolaan kelas yang baik, diharapkan dapat menciptakan suasana belajar siswa yang kondusif, sehingga mencegah terjadinya penyimpangan-penyimpangan tingkah laku peserta didik yang dapat mengganggu kegiatan belajar mengajar.

\section{SIMPULAN}

1. Pengelolaan kelas mendapat nilai capaian responden sebesar 76,63 dengan kategori cukup baik, sedangkan minat belajar nilai capaian responden sebesar 62,53 dengan kategori cukup baik.

2. Berdasarkan analisis data pada hasil penelitian bahwa terdapat pengaruh yang signifikan antara pengelolaan kelas terhadap hasil belajar siswa kelas X mata pelajaran ekonomi di SMA Negeri 8 Kota Jambi diperoleh ANOVA, nilai $\mathrm{F}=9,563$ dengan $\alpha(\mathrm{sig})=0,000$. Oleh karena $\alpha(\mathrm{Sig})<0,05$, maka regresi dapat digunakan untuk memprediksi pengelolaan kelas pada taraf kepercayaan 95\%. Pada coefficient nilai B constant $=69,652$, menyatakan bahwa jika variabel pengelolaan kelas diabaikan, maka hasil belajar $=69,652$. Sedangkan, nilai variabel untuk pengelolaan kelas (X1) adalah 0,141.

3. Berdasarkan analisis data pada hasil penelitian bahwa terdapat pengaruh yang signifikan antara minat belajar terhadap hasil belajar siswa kelas X mata pelajaran ekonomi di SMA Negeri 8 Kota Jambi diperoleh ANOVA, nilai $\mathrm{F}=9,740$ dengan $\alpha(\mathrm{sig})=0,031$. Oleh karena $\alpha(\mathrm{Sig})<0,05$, maka regresi dapat digunakan untuk 
Redi Indra Yudha, Pengaruh Pengelolaan Kelas dan Minat Belajar terhadap Hasil Belajar Siswa pada Mata Pelajaran Ekonomi Kelas X di SMA Negeri 8 Kota Jambi

memprediksi minat belajar pada taraf kepercayaan 95\%. Pada coefficient nilai B constant $=64,109$, menyatakan bahwa jika variabel minat belajar diabaikan, maka hasil belajar $=64,109$. Sedangkan, nilai variabel untuk minat belajar (X2) adalah 0,106.

4. Berdasarkan analisis data pada hasil penelitian bahwa terdapat pengaruh yang signifikan antara pengelolaan kelas dan minat belajar terhadap hasil belajar siswa kelas X mata pelajaran ekonomi di SMA Negeri 8 Kota Jambi. Berdasarkan nilai B constant dan X, dapat dibuat suatu persamaan regresi yaitu $\mathrm{Y}=\mathrm{a}+\mathrm{X} 1+\mathrm{X} 2=64,046+$ $0,201+0,291$. Dan, untuk $t$ hitung $\mathrm{X} 1=2,010$, dan $\mathrm{t}$ hitung $\mathrm{X} 2=2,856$ maka $t$ hitung $>\mathrm{t}$ tabel,. Hal ini berarti, bahwa t hitung $>\mathrm{t}$ tabel.

\section{Saran}

Dalam penelitian ini membuktikan bahwa pengelolaan kelas dan minat belajar dapat memberikan pengaruhnya terhadap capaian hasil belajar siswa, maka ada beberapa saran yang penulis dapat berikan sebagai berikut :

1. Seorang guru mampu untuk lebih memanajemen kelas dengan lebih baik sehingga terciptanya suasana belajar yang kondusif dan nyaman bagi siswa, sehingga pelaksanaan proses kegiatan belajar mengajar dapat berjalan secara optimal.

2. Siswa hendaknya dapat membagi waktu sehingga tidak ada pelajaran yang terganggu serta dapat menjaga sikap belajarnya selama proses pembelajaran. Selain itu, siswa diharapkan mampu untuk membentuk kelompok belajar dan mengulang kembali pelajaran yang telah diberikan.

\section{DAFTAR PUSTAKA}

Ahmadi, Abu dan Widodo Supriyono. 2013. Psikologi Umum. Jakarta : PT. Rineka Cipta.

Dimyati dan Mudjiono. 2005. Belajar dan Pembelajaran. Jakarta : PT. Rineka Cipta.

Djamarah, S.B. 2009. Strategi Belajar Mengajar. Jakarta : PT. Rineka Cipta.

Purwanto, Ngalim. 2014. Evaluasi Hasil Belajar. Yogyakarta : Pustaka Belajar.

Sudjana, N. 2009. Penilaian Hasil Proses Belajar Mengajar. Buku 1. Bandung : Remaja Rosdakarya.

Supriyatin, T. 2010. (Skripsi). Pengaruh Minat Belajar dan Pengelolaan Kelas Terhadap Prestasi Belajar Akuntansi Kelas XI IS SMA Negeri 1 Tengaran Tahun Ajaran 2009/2010. Jurusan Akuntansi, Fakultas Ekonomi, Universitas Negeri Semarang. (skripsi dipublikasikan)

Syekh, Said. 2011. Pengantar Statistik Ekonomi dan Sosial. Jakarta : Gaung Persada.

Thidhomanto, Al. 2010. Meraih Sukses Dengan Kecerdasan Emosional. Jakarta : Gramedia.

Usman, M. Uzer. 2003. Menjadi Guru Profesional. Bandung : Remaja Rosda Karya. 